Article

\title{
Evaluation of Filamentous Fungal Biomass Cultivated on Vinasse as an Alternative Nutrient Source of Fish Feed: Protein, Lipid, and Mineral Composition
}

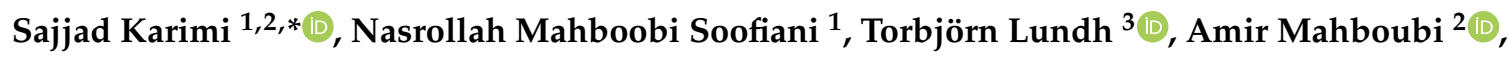 \\ Anders Kiessling ${ }^{3}$ and Mohammad J. Taherzadeh ${ }^{2}{ }^{2}$ \\ 1 Fisheries Division, Department of Natural Resources, Isfahan University of Technology, Isfahan 8415683111, \\ Iran; soofiani@cc.iut.ac.ir \\ 2 Swedish Centre for Resource Recovery, University of Borås, 50190 Borås, Sweden; \\ amir.mahboubi_soufiani@hb.se (A.M.); Mohammad.Taherzadeh@hb.se (M.J.T.) \\ 3 Department of Animal Nutrition and Management, Swedish University of Agricultural Sciences, \\ 75007 Uppsala, Sweden; Torbjorn.Lundh@slu.se (T.L.); Anders.Kiessling@slu.se (A.K.) \\ * Correspondence: sajjad.karimi@hb.se
}

Received: 25 October 2019; Accepted: 27 November 2019; Published: 2 December 2019

\begin{abstract}
The rapid growth of aquaculture and scarcity of conventional fish feed supplements has prompted the introduction of new sustainable supplementation sources. In this study, the potential of five strains of fungal biomass of Ascomycetes and Zygomycetes edible filamentous fungi, Aspergillus oryzae, Neurospora intermedia, Rizhopus oryzae, Monascus purpureus, and Fusarium venenatum, cultivated on vinasse, a by-product of the bioethanol industry, as alternative protein sources for fishmeal in the fish diet was evaluated. It was observed that $5 \%$ vinasse with an initial $\mathrm{pH}$ of 5-6.5 can support fungal biomass yields of $34.3 \pm 2.4-118.5 \pm 3.9 \mathrm{~g} \mathrm{DM} / \mathrm{L}$ for $A$. Oryzae, N. intermedia, and R. oryzae. High protein contents of about $44.7 \%, 57.6 \%$, and $50.9 \%(w / w)$, and fat contents of $7.0 \%, 3.5 \%$, and $5.5 \%(w / w)$ were obtained for $A$. oryzae, $N$. intermedia, and R. oryzae, respectively. The latter three fungi species contained noticeable amino acid contents, including promising profiles of amino acids that are highly compatible with those of fishmeal. These findings provide evidence that fungal biomasses, with their relatively high protein content, good amino acid profiles, and other essential nutrients, are a promising supplementation alternative that can be produced from low-value by-products and organic-rich waste streams like vinasse to meet the dietary protein requirements in fish feed.
\end{abstract}

Keywords: aquaculture; vinasse; protein content; fishmeal replacement; fish diet; amino acid profile

\section{Introduction}

Aquaculture has expanded rapidly during the last two decades. According to the Food and Agriculture Organization [1] annual report, fish production has increased by $7.1 \%$ throughout aquaculture in the last decade, while wild fish capture fisheries have been stagnant since 1980, followed by a decreasing trend since 2011 [1]. Of the total of 170.9 million tons of fish produced (including both captured and farmed), 80.0 million tons $(46.8 \%)$ is provided by aquaculture. Under intensive fish culture systems, fish production is significantly dependent on artificial feed supplementation [1]. Fishmeal is the major ingredient of feed supplements that meet the protein requirements of the fish diet [2]. However, fishmeal production is strongly dependent on the capture of wild fish. Over-exploitation of wild fish stocks has reached its maximum sustainable level [3]. It is expected that $16 \%$ of the total fish captured from the natural resources will be used to produce fishmeal by 2030. Along with aquaculture growth, high global demands for fishmeal and the scarcity of resources have led to an incredible increase of fishmeal price in recent years [4]. Meeting fishmeal demands for the animal 
rearing industry, particularly for aquaculture, is a critical challenge in aquaculture expansion [5]. Hence, finding alternative and renewable sources for either the partial or total replacement of fishmeal in the fish diet has received great attraction in recent years [6-8].

A potential alternative protein source for fishmeal must have compatible nutritional values in its protein content, amino acid profile, and amino acid balance. Large varieties of plant-based protein sources have been reported as potential fishmeal alternatives in the literature; these alternatives include soybean meal [9-11], lupine [12], rapeseed and canola meal [13], pea [14], cottonseed meal [15], and corn gluten [16]. However, their low digestibility, lower feed intake [17], adverse effects on microbiota and intestine structure [14], and high amount of anti-nutrients (such as protease inhibitors, lectin, phytic acid, saponins, glucosinolates, tannins, gossypol, and anti-vitamins that are involved in growth reduction and immune system impairment) have limited their application in fish diets [18]. Although animal-based protein sources, such as fish processing wastes [19], meat, bone and blood meal [20,21], and feather meal [22], have some advantages over plant-based ones, such as higher digestibility and the absence of anti-nutrient factors, they are costly and have limited availability [23]. Furthermore, there are ethical and logical challenges in using food ingredients that can be used directly as human food for fish feed ingredients. In this regard, concerns for the future availability of resources and recent breakthroughs in industrial biotechnology have initiated a new era for the application of microbial protein sources in fish feed.

Single-cell proteins, such as microalgae, bacteria, and fungi, are microbial protein sources that can be potentially utilized as ingredients in fish feed. Among them, filamentous fungi are versatile microorganisms that can grow on a very wide range of organic materials. Their high protein content, good fatty acid composition, and the presence of other nutrients (such as vitamins, minerals, antioxidants, and immune stimulant components) emphasize their potential to be introduced as suitable fish feed ingredients [23]. Filamentous fungi are employed in different areas, including the bio-ethanol industry, enzymes, organic acid production, and more recently in food industries. Filamentous fungi are able to degrade complex substrates using various enzymatic systems such as amylases, lipases, proteases, pectinases, and phytases, and then easily assimilate simple components and convert them to value-added products, such as organic acids, ethanol, and fungal biomass [24]. Some species of fungi, such as Aspergillus spp., Neurospora spp., Rhizopus spp., Fusarium spp., and Monascus spp. are categorized as GRAS (generally regarded as safe) and have food applications. Filamentous fungi, particularly Aspergillus spp. and Neurospora spp., have been used traditionally in some indigenous East Asian foods (e.g., Oncom, Koji, and miso) and beverages (e.g., Sake, Shoyu, and Vinegar). Fusarium venenatum is a well-known strain of edible filamentous fungi involved in mycoprotein production known as Quorn. Depending on the fungal species and cultivation conditions (e.g., the substrate's composition), a filamentous fungal biomass can contain approximately $50 \%$ protein (dry weight). In addition to protein content, the presence of essential fatty acids and minerals make them a valuable nutritious product that can be used as an alternative protein source in fishmeal [23].

However, the main challenge in the production of microbial biomass is the provision of a reasonably priced organic-rich cultivation medium. Applying organic-rich industrial waste or by-product streams to the traditional fungi cultivation procedure could address concerns about both fungal biomass production costs and the unsavory environmental effects of industrial waste disposal. Accordingly, several industrial by-products have been investigated as microbial culture media [23].

Vinasse, the main by-product of the bio-ethanol production industry, is rich in chemicals, organic compounds, and micro and macronutrients that can be used as a suitable substrate in the submerged cultivation of microorganisms, including filamentous fungi. Molasses is used in bio-ethanol plants to produce ethanol [25]. After ethanol extraction, the residual liquor, a brownish-black and dark liquid known as vinasse, remains [26]. Vinasse has a $\mathrm{pH}$ of 3.5-5 (COD 50-150 g/L, and 30-70\% COD is BOD) [26], and its $\mathrm{K}^{+}, \mathrm{Ca}^{2+}, \mathrm{Mg}^{2+}, \mathrm{Cl}^{-}$, and $\mathrm{SO}_{4}{ }^{2-}$ concentrations are relatively high [27]. The abovementioned environmentally undesirable characteristics become a matter of concern when the production of $1 \mathrm{~m}^{3}$ of ethanol results in $10-15 \mathrm{~m}^{3}$ vinasse production [28]. Currently, the main 
application of vinasse is in fertirrigation [29]. However, the long-term use of vinasse leads to soil and water pollution, changes in the physical and chemical structure of the soil, salinization and sodification, eutrophication of water bodies and instability in soil structures, undesirable odors, and an inhibition of plant germination $[24,30]$. Therefore, finding efficient solutions to mitigate the adverse environmental effects of the improper application of vinasse is of great importance.

Various applications have been suggested for vinasse, mainly based on the bioconversion of vinasse to value-added products. According to the its high nutritional properties of, vinasse is proposed as a nutritive substrate for various microorganism cultivation [31]. Aparicio, Benimeli, Almeida, Polti, and Colin [26] and Santana, Cereijo, Teles, Nascimento, Fernandes, Brunale, Campanha, Soares, Silva, Sabaini, Siqueira, and Brasil [27] used vinasse as a substrate for Actinobacteria and microalgaemicractinum sp. and C. biconvexa biomass production, respectively. Also, vinasse was used as a cultivation medium for microalgae micractinum sp. and scenedesmus sp. [32,33]. A new application of vinasse as a substrate to produce filamentous fungi biomass and fungal products is a promising approach that could meet both the demand for a cheap media for filamentous fungi cultivation and reduce amount of this environmentally unpleasant material. Nitayavardhana and Khanal [34] and Nitayavardhana et al. [35] were the first to propose vinasse as a highly potent substrate for filamentous fungi cultivation. The authors cultivated Rhizopus microsporus and Rhizopus oligosporus in vinasse and yielded a protein-rich fungal biomass. In addition, Nair and Taherzadeh [28] applied vinasse to the production of fungal biomass and produced $202.4 \mathrm{~g}$ Neurospora intermedia and $222.8 \mathrm{~g}$ Aspergillus oryzae per liter of vinasse through submerged fermentation.

In this study, the potential of vinasse to support the cultivation of five different species of filamentous fungi, A. oryzae, R. oryzae, N. intermedia, M. purpureus, and F. venenatum, were investigated. The metabolic production and capacity of these fungi to utilize sugar and other organic components as a substrate for growth (resulting in a reduction of the chemical oxygen demand (COD) in vinasse) were also measured. Moreover, the different nutritional aspects of the produced fungal biomass, including protein, lipid, and mineral content, were analyzed to evaluate vinasse's potential to be an alternative ingredient for fishmeal in aqua-feed production.

\section{Materials and Methods}

\subsection{Vinasse Characteristics}

Vinasse samples were provided by Sepahan Bio-product Company (Isfahan, Iran). The vinasse was derived from the ethanol production from molasses. The required amount of vinasse was prepared and stored in a cold-room at $4{ }^{\circ} \mathrm{C}$ until further use. Some of the general characteristics and chemical composition of the vinasse sample used for the present study, including total and suspended solids, nitrogen content, and COD content are summarized in Table 1.

\subsection{Fungi Species}

Spores for the five species of edible food-grade filamentous fungi used in this study, Aspergillus oryzae CBS 819.72, Neurospora intermedia CBS 131.92, Rhizopus oryzae CCUG 61,147 (Culture Collection University of Gothenburg, Sweden), Monascus purpureus CBS 109.07, and Fusarium venenatum ATCC 20,334 (American Type Culture Collection, USA), were obtained from the University of Gothenburg microbial culture collection (Gothenburg, Sweden). Spores were preserved in Potato Dextrose Agar (PDA) plates containing $4 \mathrm{~g} / \mathrm{L}$ potato extract, $20 \mathrm{~g} / \mathrm{L}$ glucose, and $15 \mathrm{~g} / \mathrm{L}$ agar. The inoculated PDA plates were incubated for $3-5$ days at $30^{\circ} \mathrm{C}$ and then stored at $4{ }^{\circ} \mathrm{C}$ in a fridge until being used as a cultivation inoculum. For preparation of the inoculum solution, the spores were released and collected from the PDA. For this purpose, $20 \mathrm{~mL}$ sterile distilled water was added to the PDA plates, and the spores were then released using gentle agitation and scraping of surface of the culture. The supernatant mixture, containing spores with a concentration of $3.9 \times 10^{5}-3.8 \times 10^{6}$ spores $/ \mathrm{mL}$, was collected, and $500 \mu \mathrm{L}$ of this mixture was added to the Erlenmeyer shake-flasks. 
Table 1. Chemical composition and general characteristics of the substrate (concentrated vinasse) used for culturing filamentous fungi.

\begin{tabular}{|c|c|c|c|}
\hline Parameter & Value & & Concentration (ppm) \\
\hline $\mathrm{pH}$ & $5.5 \pm 0.09$ & Minerals & \\
\hline Total solids (\%) & $65.27 \pm 1.45$ & Aluminum (Al) & 5.5 \\
\hline Volatile solid (\%) & $28.93 \pm 0.37$ & Arsenic (As) & 0 \\
\hline Ash (\%) & $25.16 \pm 0.2$ & Barium (Ba) & 0.1 \\
\hline $\operatorname{COD}(\mathrm{g} / \mathrm{L})$ & $835 \pm 22$ & Bor (B) ppm & 7 \\
\hline SCOD (soluble COD) $(\mathrm{g} / \mathrm{L})$ & $740 \pm 14$ & Cadmium (Cd) & 0 \\
\hline Soluble sugar $(\mathrm{g} / \mathrm{L})$ & & Chromium (Cr) & 0 \\
\hline Arabinose & $1.39 \pm 0.24$ & Cobalt (Co) & 0 \\
\hline Cellobiose & $19.27 \pm 1.15$ & Cupper $(\mathrm{Cu})$ & 15 \\
\hline Fructose & $11.03 \pm 0.68$ & Iron $(\mathrm{Fe})$ & 350 \\
\hline Galactose & $3.42 \pm 0.17$ & Lead $(\mathrm{Pb})$ & 0 \\
\hline Glucose & $14.4 \pm 0.78$ & Manganese & 35 \\
\hline Mannose & $0.76 \pm 0.04$ & Molybdenum (Mo) & 0 \\
\hline Sucrose & $4.71 \pm 0.14$ & Nickel (Ni) & 0.6 \\
\hline Xylose & $0.88 \pm 0.05$ & Potassium (K) & 87,220 \\
\hline Organic Acid, Metabolite (g/L) & & Selenium (Se) & 2.5 \\
\hline Acetic acid & $39.7 \pm 1.55$ & Strontium (Sr) & 3.4 \\
\hline Ethanol & $1.1 \pm 0.11$ & Zinc (Zn) & 50 \\
\hline Glycerol & $90.7 \pm 3.75$ & & Concentration (\%) \\
\hline \multirow[t]{4}{*}{ Lactic acid } & $102.6 \pm 7.09$ & Calcium (Ca) & 1.2 \\
\hline & & Magnesium (Mg) & 0.1 \\
\hline & & Phosphorus (P) & 0.03 \\
\hline & & Sodium (Na) & 1 \\
\hline
\end{tabular}

Different concentrations of vinasse $(5 \%, 10 \%, 15 \%, 20 \%$, and $50 \%)$ were used to investigate the biomass yield. Original vinasse was diluted by adding distilled water to obtain the defined concentrations. $\mathrm{pH}$ was adjusted by adding required amount of $\mathrm{H}_{2} \mathrm{SO}_{4}(2 \mathrm{M})$ and $\mathrm{NaOH}(2 \mathrm{M})$ to get the required $\mathrm{pH}$.

\subsection{Cultivation in Shake-Flasks}

Cultivations were carried out in $250 \mathrm{~mL}$ Erlenmeyer shake-flasks containing $100 \mathrm{~mL}$ of the vinasse medium. All used media were autoclaved separately at $121^{\circ} \mathrm{C}$ for $20 \mathrm{~min}$. The cultivation was done in a water-bath at $35^{\circ} \mathrm{C}$ and $125 \mathrm{rpm}(9 \mathrm{~mm}$ orbital shaking radius) for $72 \mathrm{~h}$. In order to monitor $\mathrm{pH}$, metabolite production, and sugar consumption, $3 \mathrm{~mL}$ samples were collected at $24 \mathrm{~h}$ intervals $(0 \mathrm{~h}, 24 \mathrm{~h}$, $48 \mathrm{~h}$, and $72 \mathrm{~h}$ ) during cultivation, followed by $10 \mathrm{~min}$ centrifugation at $20,000 \times \mathrm{g}$. The supernatant solution was then separated and filtered using $0.2 \mu \mathrm{m}$ pore size filters and stored at $-20^{\circ} \mathrm{C}$ for further analysis by HPLC. Once the cultivation was complete, the biomass was gently separated from the medium using a fine mesh sieve $\left(1 \mathrm{~mm}^{2}\right)$ and washed carefully with distilled water and dried at $70{ }^{\circ} \mathrm{C}$ in an oven until reaching a constant weight.

\subsection{Analytical Procedures}

The total solid, suspended solid, and ash content of the samples were measured according to the National Renewable Energy Laboratory (NREL) method [36]. An analysis of the anabolic and catabolic metabolites from the fungi cultivation was performed using HPLC. Acetic acid, ethanol, glucose, glycerol, and lactic acid were analyzed using an analytical hydrogen-based ion exchange column (Aminex HPX-87H, $250 \times 4$ mm, Bio-Rad, California, CA, USA). The mobile phase consisted of $5 \mathrm{mMH}_{2} \mathrm{SO}_{4}$ with an elution rate of $0.6 \mathrm{~mL} / \mathrm{min}$ at $60^{\circ} \mathrm{C}$. The HPLC-system consisted of Waters alliance separation modul2695 (Waters Corporation, Milford, Massachusetts, MA, USA) operating at the $210 \mathrm{~nm}$ wavelength, which was used with a refractive index (RI) detector (Waters 2414).

A Microwave Plasma Atomic Emission Spectroscope (MP-AES 4200, Agilent Technologies, Santa Clara, CA, USA) was employed to measure the availability and concentration of different ionic 
components. The total chemical oxygen demand (COD) was determined using a NANOCOLOR COD $15,000 \mathrm{kit}$, with photometric determination of the samples done using NANOCOLOR photometers (Macherey-Nagel, Düren, Germany).

The fungal spore concentration was measured using a Bürker counting chamber under a light microscope (Carl Zeiss Axiostar plus, Germany). Minerals were analyzed using plasma emission spectroscopy (Spectro Analytical Instruments $\mathrm{GmbH} \&$ Co., Kleve, Germany), with samples extracted with $7 \mathrm{M} \mathrm{HNO}_{3}$, according to Bahlsberg-Pålsson [37]. Total nitrogen (N) was determined according to the Kjeldahl method using a 2020 digester and a 2400 Kjeltec Analyser unit (FOSS Analytical A/S, Hilleröd, Denmark). Crude protein content was then calculated by multiplying the factor 6.25 with the $\mathrm{N}$ value from Kjeldahl [38]. Amino acid content in the feed was analyzed by an accredited laboratory (Eurofin, Lidköping, Sweden) using the SS-EN ISO13903:2005 method.

Crude fat content was measured as described by the Official Journal of the European Communities (1984). An extraction unit (1047 Hydrolysing Unit and a Soxtec System HT 1043, FOSS Analytical A/S) was also used to perform crude fat analysis. The Folch method was used to extract lipids from the samples (chloroform:MeOH (2:1 V/V)) [39]. Fatty acid methyl esters (FAME) were methylated following the method described by Appelqvist [40]. The lipids were quantified using heptadecanoic acid (C17:0) as an internal standard (Larodan, Karolinska Institutet Science Park, Solna Sweden). FAME were analyzed with a GC (Agilent 6890, USA) via a flame ionization detector (FID), Split/Splitless Capillary Inlet, and a 7683 auto sampler using a SGE BPX70 capillary $50 \mathrm{~m} \varnothing 0.22 \mathrm{~mm} / 0.25 \mu$ film thickness.

\section{Results and Discussions}

In order to investigate the potential of vinasse in the production of a fungal biomass that could further be applied in fish feed supplementation, five different strains of edible filamentous fungi were cultivated on vinasse. Throughout cultivation, changes in the substrate and metabolite concentrations in the medium, as well as $\mathrm{pH}$ and COD, were monitored. The harvested biomass was subjected to further analysis of its nutrients in order to evaluate its supplementation possibilities in fish feed.

\subsection{Filamentous Fungi Cultivation in Vinasse}

\subsubsection{The Effects of Vinasse Concentration on Fungal Cultivation}

The original vinasse sample, delivered from the company, was concentrated. Therefore, its microbial activity was very low because of its acidic condition (below $\mathrm{pH}$ 5) and low water content [25]. Due to its high COD, different levels of dilution for vinasse were needed for it to be utilized as a cultivation substrate for filamentous fungi.

Five different dilutions of vinasse were used for the cultivation of filamentous fungi. The results of the evaluated parameters that made considerable changes in the biomass yield (including medium concentration and cultivation $\mathrm{pH}$ ) are tabulated in Table 2. Other parameters, such as the optimum cultivation temperature for each species and shaking rate, were previously investigated, and the optimal cultivation conditions were applied in the current study based on Mahboubi Soufiani et al. [41]. According to the collected data (Table 2), the 95\% diluted ( $v / v$ ) vinasse supports the best growth for A. oryzae, N. intermedia, and R. oryzae. However, the two other species, M. purpureus and F. venenatum, did not grow in any of the preparations. The maximum fungal biomass yield was $103.0 \pm 2.7,78.6 \pm 1.0$, and $27.9 \pm 2.0(\mathrm{~g} \mathrm{DM} / \mathrm{L})$ for $A$. oryzae, $N$. intermedia, and $R$. oryzae, respectively, in $5 \%$ vinasse medium. The initial medium COD was around $21(\mathrm{~g} / \mathrm{L})$ for the $5 \%$ vinasse solution, which may have contributed to the better growth of all three species.

\subsubsection{The Effect of $\mathrm{pH}$ on Fungal Cultivation in Vinasse}

In a $5 \%$ vinasse medium, the best initial $\mathrm{pH}$ for cultivation was $6.5,5.5$, and 5 for A. oryzae, $N$. intermedia, and R. oryzae, resulting in biomass yields of $118.5 \pm 3.9,85.1 \pm 3.9$, and $34.3 \pm 2.4$ (g dry biomass/L), respectively (Table 2). Nitayavardhana and Khanal [34] previously reported a 
similar result for the cultivation of $R$. oryzae using three different type of vinasse. Considering the original $\mathrm{pH}$ of vinasse (5.48), the addition of acid or alkali solutions could be useful to reach the optimum $\mathrm{pH}$ for each species. However, in the case of $N$. intermedia, which showed maximum growth around the original vinasse $\mathrm{pH}$, this may be of great importance when considering the industrial scale production of fungal biomass from vinasse.

Table 2. Filamentous fungi cultivation in vinasse: Optimization of the substrate concentration and initial cultivation $\mathrm{pH}$ for maximum growth $(n=2)$. Biomass is presented as $\mathrm{g} \mathrm{DM} / \mathrm{L} \pm \mathrm{SD}$.

\begin{tabular}{|c|c|c|c|c|c|}
\hline Culture Condition & A. Oryzae & N. Intermedia & R. Oryzae & M. Purpureus & F. Venenatum \\
\hline \multicolumn{6}{|c|}{ Concentration $(\% v / v)$} \\
\hline $5 \%$ & $103.0 \pm 2.7$ & $78.6 \pm 1.0$ & $27.9 \pm 2.0$ & 0.0 & 0.0 \\
\hline $10 \%$ & $91.1 \pm 3.6$ & $70.0 \pm 2,4$ & $23.6 \pm 1,2$ & 0.0 & 0.0 \\
\hline $15 \%$ & $66.9 \pm 1.5$ & $56.2 \pm 1.9$ & $14.7 \pm 1.3$ & 0.0 & 0.0 \\
\hline $20 \%$ & $31.6 \pm 2.4$ & $9.3 \pm 0.6$ & 0.0 & 0.0 & 0.0 \\
\hline $50 \%$ & 0.0 & 0.0 & 0.0 & 0.0 & 0.0 \\
\hline \multicolumn{6}{|c|}{$\begin{array}{c}5 \% \text { Concentration } \\
\mathrm{pH}\end{array}$} \\
\hline 5.0 & $88.6 \pm 4.2$ & $79 \pm 1.7$ & $34.3 \pm 2.4$ & 0.0 & 0.0 \\
\hline 5.5 & $103.1 \pm 5.3$ & $85.1 \pm 3.4$ & $25 \pm 1.1$ & 0.0 & 0.0 \\
\hline 6.0 & $111.2 \pm 4.2$ & $77.2 \pm 1.9$ & $21.1 \pm 0.8$ & 0.0 & 0.0 \\
\hline 6.5 & $118.5 \pm 3.9$ & $75 \pm 3.1$ & $29.9 \pm 1.7$ & 0.0 & 0.0 \\
\hline
\end{tabular}

\subsubsection{The Organic Removal and Metabolite Production of Fungi in Vinasse}

The substrate assimilation and metabolite production profile during the $72 \mathrm{~h}$ cultivation of $A$. oryzae, $N$. intermedia, and R. oryzae is illustrated in Figure 1. Most of glucose and acetic acid were consumed in the first $24 \mathrm{~h}$ of cultivation by $A$. oryzae and N. intermedia. However, only $20 \%$ of the glucose content was consumed by $R$. oryzae during the same period. This might be due to the better adaptability of $A$. oryzae and $N$. intermedia to the substrate, which has resulted in a shorter lag phase. Regarding acetic acid assimilation, $N$. intermedia and $R$. oryzae consumed about $69.2 \% \pm 0.8 \%$ and $62.6 \% \pm 0.5 \%$ of the initial amount in $24 \mathrm{~h}$, while only $14.4 \% \pm 0.3 \%$ of the initial amount of acetic acid was utilized by $A$. oryzae. After $72 \mathrm{~h}$ cultivation, $54.7 \% \pm 0.5 \%, 84.8 \% \pm 0.6 \%$, and $80.1 \% \pm 0.9 \%$ of acetic acid was consumed by $A$. oryzae, N. intermedia, and R. oryzae, respectively. Similarly, Ghasemian et al. [42] reported that A. oryzae; $N$. intermedia, and $R$. oryzae can effectively utilize acetic acid as a growth substrate. They stated that, although acetic acid consumption is dependent on its concentration, biomass yield is increased when acetic acid is added to the cultivation medium. During cultivation, glycerol was efficiently utilized by $A$. oryzae. While glycerol consumption was poor during the first $24 \mathrm{~h}$ of cultivation, it increased from 24 to $48 \mathrm{~h}$, so glycerol content was reduced in the media by $88.6 \% \pm 0.2 \%$. However, $N$. intermedia and R. oryzae showed a limited reduction rate for glycerol-9.6 \pm 0.5 and $14.7 \% \pm 0.3 \%$, respectively. A. oryzae was able to utilize glycerol as a carbon source. When a nitrogen source, such as yeast extract, was present in the cultivation medium, $A$. oryzae could assimilate $25.6 \mathrm{~g} / \mathrm{L}$ of the total $27 \mathrm{~g} / \mathrm{L}$ available glycerol during a $96 \mathrm{~h}$ cultivation period [41].

Another metabolite of interest during the cultivation of the aforementioned fungal strains on vinasse is ethanol. The highest ethanol production $(4.6 \pm 0.1 \mathrm{~g} / \mathrm{L})$ on $5 \%$ vinasse took place when employing $R$. oryzae. A. oryzae was the second-best ethanol producer, with about $3.4 \pm 0.2 \mathrm{~g} / \mathrm{L}$, followed by $N$. intermedia $(1.8 \pm 0.0 \mathrm{~g} / \mathrm{L})$. Most ethanol production occurred during the first $24 \mathrm{~h}$, followed by its utilization by filamentous fungi as cultivant. Similar phenomena have been reported by FazeliNejad et al. [43] for Rizhopus sp., utilizing ethanol as a carbon source after $48 \mathrm{~h}$ cultivation. From an industrial biorefinery viewpoint, ethanol produced through fungal cultivation in vinasse has the potential to be reintroduced into the molasses fermentation broth processed downstream, which has already been established to increase process efficiency. Considering the results acquired in this study, up to $70.2 \mathrm{~L}$ more ethanol per $1 \mathrm{~m}^{3}$ ethanol produced from molasses can be added to the production stream by fungal cultivation in residual vinasse. 

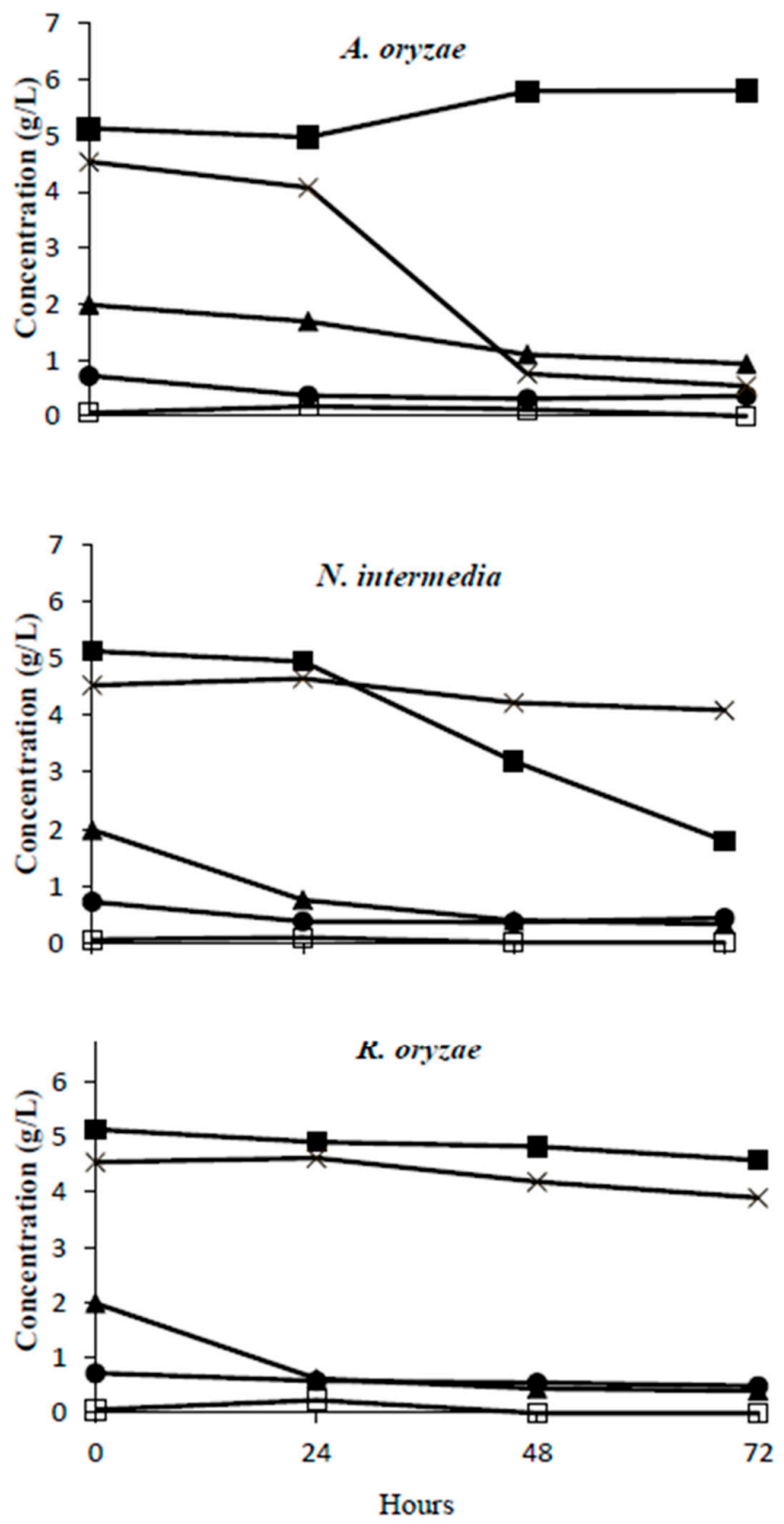

Figure 1. Substrate utilization and ethanol production of $A$. oryzae $(\mathrm{pH}=6.5), N$. intermedia $(\mathrm{pH}=5.5)$, and $R$. oryzae $(\mathrm{pH}=5)$ at a $5 \%$ concentration of vinasse (glucose $(\bullet)$, lactic acid $(\boldsymbol{\square})$, glycerol $(\times)$, ethanol $(\square)$, and acetic acid ( $\mathbf{\Lambda})$ ).

Considering the changes mentioned at the substrate and metabolite level during cultivation, the COD content of vinasse was also altered. The initial COD was measured to be around $835 \pm 8 \mathrm{~g} / \mathrm{L}$ for the as-received vinasse, while after $72 \mathrm{~h}$ of fungal cultivation, it reduced to $450 \pm 3,485 \pm 7$ and $555 \pm 4 \mathrm{~g} / \mathrm{L}$ for A. oryzae, N. intermedia, and R. oryzae, respectively, which represent $46.1 \%, 41.9 \%$, and $33.5 \%$ of total vinasse COD. Organic material reduction, which is carried out at a range of $33-46 \%$ of the initial COD content, can address environmental issues arising from the conventional dispose of vinasse.

\subsection{Nutritional Characteristics of Fungal Biomass Cultivated on Vinasse}

Different nutritional properties of filamentous fungal biomass, such as dry matter, protein, lipid, and mineral content, as well as the amino acid and fatty acid profile for A. oryzae, N. intermedia, and $R$. oryzae were measured, and the results were presented. 


\subsubsection{Protein and Amino Acid Composition of Fungal Biomass Cultivated on Vinasse}

Protein inclusion and amino acid balance are the most important factors in formulating a fish diet; therefore, protein sources have great importance in fish feed from biological, functional, and economic points of view. Considering the results presented in Table 3 , among the three species investigated, $N$. intermedia contained the highest protein content (57.6\%), whereas A. oryzae had the lowest protein content $(44.7 \%)$, besides its high biomass yield in the vinasse medium. Proteins are the primary organic components of fish tissue, comprising 65-75\% of a fish's dry weight. As with all animals, a fish diet's protein to energy ratio, amino acid profile, protein digestibility, non-protein energy sources, environmental conditions, and stage of life are of critical importance. Fish are the most protein-dependent animal, with a CP (crude protein) retention rate of around 30\%, while that of chicken and pig has been measured to be around 25\% and 13\%, respectively [44]. Regardless of fish or shrimp species and the life stage of the organism, aqua-feeds should contain 26 to $55 \%$ protein, and inadequate protein supplementation in the feed can hamper fish growth [45], while other animals, for example swine, do not have certain requirements for \%CP (ranging from less than 10\% to $20 \% \mathrm{CP}$ (dry matter)), with their growth more dependent on amino acid provisions [46]. Fishmeal and soybean meal, the two most usual protein supplementation sources in aqua-feed, contain $62-70 \%$ and $46-50 \%$ crude protein, respectively [5]. Considering this, new protein sources, such as fungal biomass, with comparatively high protein content (see Table 3 for a comparison), have the potential to be used as an alternative protein source for fishmeal and soya.

Table 3. Proximate composition and AA profile of A. oryzae, N. intermedia, and R. oryzae, fishmeal, and soybean meal (SBM).

\begin{tabular}{|c|c|c|c|c|c|c|c|c|c|c|}
\hline & \multicolumn{5}{|c|}{ AA (g/Kg DM) } & \multicolumn{5}{|c|}{ AA ( $\%$ of Total AA Content) } \\
\hline & AO & NI & RO & FM & SBM & AO & NI & RO & FM & SBM \\
\hline DM (\%) & 93.6 & 94.9 & 92.3 & 94.3 & 87.6 & & & & & \\
\hline $\mathrm{CP}(\%)$ & 44.7 & 57.6 & 50.9 & 62.6 & 43.3 & & & & & \\
\hline CF $(\%)$ & 7.0 & 3.5 & 5.5 & 8.9 & 1.7 & & & & & \\
\hline \multicolumn{11}{|c|}{ Indispensable Amino Acids } \\
\hline Arginine & 19.9 & 20.7 & 18.7 & 38.2 & 32.0 & 6.42 & 6.15 & 6.03 & 6.75 & 7.81 \\
\hline Histidine & 7.51 & 8.65 & 7.66 & 15.9 & 11.5 & 2.42 & 2.57 & 2.47 & 2.81 & 2.81 \\
\hline Isoleucine & 13.8 & 16.1 & 15.7 & 25.0 & 19.9 & 4.45 & 4.78 & 5.07 & 4.42 & 4.85 \\
\hline Leucine & 24.6 & 27.1 & 24.5 & 44.5 & 31.9 & 7.94 & 8.05 & 7.9 & 7.86 & 7.78 \\
\hline Lysine & 21.4 & 24.4 & 22.9 & 46.4 & 26.6 & 6.91 & 7.25 & 7.39 & 8.2 & 6.49 \\
\hline Methionine & 5.66 & 6.05 & 5.98 & 16.3 & 6.2 & 1.83 & 1.8 & 1.93 & 2.88 & 1.51 \\
\hline Phenylalanine & 14.2 & 15.8 & 14.6 & 24.3 & 21.7 & 4.58 & 4.69 & 4.71 & 4.29 & 5.29 \\
\hline Threonine & 16.9 & 18.1 & 16.2 & 25.6 & 17.7 & 5.45 & 5.38 & 5.23 & 4.52 & 4.32 \\
\hline Valine & 17.2 & 20.2 & 18.5 & 30.0 & 20.8 & 5.55 & 6.0 & 5.97 & 5.3 & 5.07 \\
\hline Sum & 123.9 & 136.9 & 126.24 & 236.2 & 167.5 & 45.55 & 46.67 & 46.7 & 47.03 & 45.93 \\
\hline \multicolumn{11}{|c|}{ Dispensable Amino Acids } \\
\hline Alanin & 23.7 & 27.8 & 23.7 & 39.7 & 19.0 & 7.65 & 8.26 & 7.65 & 7.02 & 4.64 \\
\hline Aspargine & 32.3 & 36.6 & 32.3 & 57.7 & 49.0 & 10.42 & 10.87 & 10.42 & 10.2 & 11.95 \\
\hline Cystein & 2.75 & 3.27 & 3.01 & 5.1 & 0.5 & 0.89 & 0.97 & 0.97 & 0.9 & 0.12 \\
\hline Glutamine & 43.3 & 47.7 & 40.9 & 77.3 & 77.0 & 13.97 & 14.17 & 13.2 & 13.66 & 18.79 \\
\hline Glycin & 17.2 & 18.9 & 16.5 & 48.0 & 18.1 & 5.55 & 5.61 & 5.32 & 8.48 & 4.42 \\
\hline Hydroxyproline & ND & ND & ND & ND & ND & ND & ND & ND & ND & ND \\
\hline Ornithine & 0.97 & ND & 0.51 & ND & ND & 0.31 & ND & 0.16 & ND & ND \\
\hline Proline & 18.5 & 14.1 & 20.2 & 28.3 & 21.6 & 5.97 & 4.19 & 6.52 & 5.0 & 5.27 \\
\hline Serine & 17.2 & 17.6 & 15.6 & 24.5 & 21.8 & 5.55 & 5.23 & 5.03 & 4.33 & 5.32 \\
\hline Tyrosine & 12.8 & 13.6 & 12.5 & 19.0 & 14.6 & 4.13 & 4.04 & 4.03 & 3.36 & 3.56 \\
\hline Sum & 168.72 & 179.57 & 165.22 & 299.6 & 221.6 & 54.44 & 53.34 & 53.3 & 52.95 & 54.07 \\
\hline
\end{tabular}


The protein quality in a diet is of crucial importance, regardless of the animal species. Therefore, the amino acid composition and the ratio of each amino acid to the total amino acid content of the supplemented protein is of particular importance in evaluating each protein source's value [48]. The amino acid profile of the obtained fungal biomass is presented in Table 4. Of the total protein content of the studied fungi species, $64.8 \%, 58.4 \%$, and $60.9 \%$ was pure amino acid content. Fishmeal and soybean meal had $90.4 \%$ and $94.6 \%$ pure amino acid content, respectively. Since crude protein is measured using the Kjeldahl $\mathrm{N}$ content multiplied by 6.25 , a high concentration of nitrogen containing compounds other than protein contributes to an overestimation of $\mathrm{CP}$-content when 6.25 is used as the correction factor in a Kjeldahl analysis. Nitrogenous components in the biomass are not necessarily limited to proteins or amino acids, as a large number of other substances, such as nucleic acids, amines, urea, ammonia, nitrates, nitrites, phospholipids, nitrogenous glycosides, etc., have nitrogen as one of their main structural constituents [49]. The cell walls in fungi species (15 to $30 \%$ of the DM of the biomass) are composed of a large amount of glucosamine derivatives [50] and also high RNA content [23].

Table 4. Fatty acid content of A. oryzae, N. intermedia, and R. oryzae, fishmeal (FM), and soybean meal (SBM).

\begin{tabular}{|c|c|c|c|c|c|c|c|c|c|c|}
\hline \multicolumn{11}{|c|}{ Fatty Acids (\% of Extracted Lipid Fraction) } \\
\hline & $\begin{array}{c}A . \\
\text { Oryzae }\end{array}$ & $\mathrm{g} / \mathrm{kg}$ & $\begin{array}{c}N . \\
\text { Intermedia }\end{array}$ & $\mathrm{g} / \mathrm{kg}$ & $\begin{array}{c}R . \\
\text { Oryzae }\end{array}$ & $\mathrm{g} / \mathrm{kg}$ & $\begin{array}{l}\text { FM } \\
(\%)\end{array}$ & $\begin{array}{c}\text { FM } \\
(\mathrm{g} / \mathrm{kg})\end{array}$ & $\begin{array}{c}\text { SBM } \\
(\%)\end{array}$ & $\begin{array}{c}\text { SBM } \\
(\mathrm{g} / \mathrm{kg})\end{array}$ \\
\hline C14:0 (Myristic acid) & 0.47 & 0.33 & 0.73 & 0.26 & 0.86 & 0.47 & 6 & 4.10 & 0.1 & 0 \\
\hline C14:1 (Myristolicacid) & 0.00 & 0.00 & 0.00 & 0.00 & 0.00 & 0.00 & 0.00 & 0.00 & 0.00 & 0.00 \\
\hline C16:0 (Palmitic acid) & 19.93 & 13.93 & 17.28 & 6.13 & 22.87 & 12.50 & 17.8 & 12.30 & 10.5 & 1.3 \\
\hline C16:1 (Palmitoleic acid) & 3.17 & 2.21 & 3.84 & 1.36 & 5.78 & 3.16 & 7.2 & 5.00 & 0.2 & 0.00 \\
\hline C18:0 (Stearic acid) & 7.73 & 5.40 & 4.97 & 1.76 & 6.26 & 3.42 & 3.6 & 2.50 & 3.8 & 0.5 \\
\hline C18:1 (Oleic acid) & 33.93 & 23.72 & 39.70 & 14.09 & 27.97 & 15.29 & 12.3 & 8.50 & 21.7 & 2.8 \\
\hline C18:1 (Vaccenic acid) & 0.48 & 0.33 & 1.97 & 0.70 & 1.42 & 0.78 & & & & \\
\hline C18:2 (Linolelaidic acid) & 32.36 & 22.62 & 29.40 & 10.43 & 34.31 & 18.76 & 2.1 & 1.40 & 53.1 & 6.8 \\
\hline C18:3 (Linolenic acid) & 0.29 & 0.20 & 0.92 & 0.33 & 0.53 & 0.29 & 1.9 & 1.30 & 7.4 & 0.9 \\
\hline C20:0 (Arachidic acid) & 0.31 & 0.22 & 0.26 & 0.09 & 0.00 & 0.00 & & & & \\
\hline C20:1 cis-11-ecosenoic acid & 0.00 & 0.00 & 0.00 & 0.00 & 0.00 & 0.00 & 6.6 & 4.5 & & \\
\hline C20:2 (cis-11,14-ecosadienoic acid) & 0.00 & 0.00 & 0.00 & 0.00 & 0.00 & 0.00 & & & & \\
\hline C20:3 (11,14,17-Eicosatrienoic acid) & 0.00 & 0.00 & 0.00 & 0.00 & 0.00 & 0.00 & & & & \\
\hline C20:4 (Arachidonic acid) & 0.55 & 0.38 & 0.36 & 0.13 & 0.00 & 0.00 & 2.4 & 1.7 & & \\
\hline C20:5n-3 (Eicosapentaenoic acid) & 0.00 & 0.00 & 0.00 & 0.00 & 0.00 & 0.00 & 9.0 & 6.2 & & \\
\hline C22:0 (Behenic acid) & 0.23 & 0.16 & 0.20 & 0.07 & 0.00 & 0.00 & & & & \\
\hline C22:1 (Erucic acid) & 0.00 & 0.00 & 0.00 & 0.00 & 0.00 & 0.00 & 7.7 & 5.3 & & \\
\hline C24:0 (Lignoceric acid) & 0.55 & 0.39 & 0.37 & 0.13 & 0.00 & 0.00 & & & & \\
\hline C24:1 (Nervonic acid) & 0.00 & 0.00 & 0.00 & 0.00 & 0.00 & 0.00 & & & & \\
\hline C22:6n-3 (Docosahexaenoic acid) & 0.00 & 0.00 & 0.00 & 0.00 & 0.00 & 0.00 & 6.6 & 4.5 & & \\
\hline Total & 100.00 & & 100.00 & & 100.00 & & & & & \\
\hline$\%$ SFA & 28.13 & 19.66 & 22.98 & 8.15 & 29.99 & 16.40 & & & & \\
\hline$\%$ MUFA & 37.57 & 26.26 & 45.51 & 16.15 & 35.17 & 19.23 & & & & \\
\hline$\%$ PUFA & 33.20 & 23.21 & 30.68 & 10.89 & 34.84 & 19.05 & & & & \\
\hline PUFA/SFA & 1.18 & & 1.34 & & 1.16 & & & & & \\
\hline
\end{tabular}

SFA: Saturated fatty acids, MUFA: Mono unsaturated fatty acids, PUFA: Poly unsaturated fatty Acids. FM and SBM [47].

Glutamine, asparagine, leucine, alanine, lysine, and arginine are the most abundant amino acids in fungal biomass that are comparable with those of fishmeal, with the exception of glycine, which is higher in fishmeal. The abovementioned amino acids represent more than $50 \%$ of the total amino acid content of the fungal biomass. Among these amino acids, lysine, arginine, and leucine are considered indispensable amino acids (IAA), since animals do not have the capacity, or are poorly capable of, synthesizing them de novo. As these IAA should be supplied to the fish diet, fungal biomass may be a promising IAA supplementation source. On the other hand, dispensable amino acids (DAA) are those that can be synthesized in the animal's body [45]. Amino acids are involved in many cellular processes, such as the synthesis and degradation of proteins, the urea cycle, energy metabolism, synthesis and metabolism of lipids, and glucose and cell signaling [51].

Lysine, the first limiting amino acid in feed, is very sensitive to heat during fish feed processing, which reduces the availability of lysine [52]. Common fishmeal contains a high amount of lysine, while plant proteins contain low amounts of lysine. Lysine serves as a key substance, playing important roles in the body, such as regulation of the carnitine synthesis responsible for the transportation of long chain 
fatty acids into the mitochondria [53] and osmoregulation [54]. Lysine is also involved in maintaining the acid-base balance, nitrogen retention in the tissue [55], reducing the fat levels of the body, and increasing muscle growth in fish by rapidly increasing the size and length of muscle fibers [56] and eventually increasing weight gain [57]. Besides reduced growth and feed efficiency, dorsal and caudal fin erosion is also a consequences of lysine deficiency in rainbow trout [58]. According to [45], the fish requirement for lysine is $3-6 \%$, which can be met by this fungal biomass. In the present study, all fungi species biomasses contain a high proportion of arginine. Arginine is involved in protein synthesis, urea production, and the metabolism of several amino acids, such as proline and glutamic acid [59]. Arginine is precursor for creatine and nitric oxide synthesis, a stimulant of insulin, and a growth hormone; therefore, it has an important role in anabolic processes [60]. However, in fish and shrimp, arginine has been shown to be an IAA due to its very poor activity in the urea cycle. Moreover, arginine has been reported to have an effect on immunological functions in mammals [61]. A supplementation of dietary arginine can modulate some innate immune mechanisms in channel catfish [62]. Buentello and Gatlin [63] found that the survival rate of channel catfish challenged with Edwardsiella ictaluri critically depended upon the dietary arginine level. Arginine also plays a crucial role in regulating endocrine and reproductive functions, as well as extra-endocrine signaling pathways [64]. The arginine requirement of fish $(6 \%)$ can be provided by the biomasses from all fungi species studied in the present investigation. As one of the most abundant amino acids in fungal biomass, leucine has a critical role in protein structures and comprises a relatively high proportion of most proteins. Fungal biomass contains even higher amounts of leucine than fishmeal. Therefore, it seems that there is no deficiency in leucine supplementation in the feed if a fungal biomass is used as the protein ingredient. Leucine is considered a functional amino acid to stimulate muscle protein synthesis and inhibit proteolysis in mammals [65].

In addition to what was described above regarding indispensable amino acids, fungal biomass is rich in glutamine, which is a conditionally indispensable amino acid [58], and asparagine and alanine, which are categorized as dispensable amino acids. Glutamine and glutamate represent $20 \%$ of the amino acids in plant and animal proteins involved in all transamination process. Glutamine and glutamate are some of the most abundant amino acids present in fish plasma and muscle and are necessary for purine and pyrimidine nucleotide synthesis, acid-base balance regulation, and protein synthesis stimulation; they also constitute the main energy substrate for enterocytes [66]. The presence of an adequate amount of glutamine in the diet enhances weight gain, feed intake, intestinal development, and digestive enzyme activity. Glutamine and glutamate are also essential for fish immunity response. The fungal biomass contains average amount of $13.5 \%$ glutamine that can support growth and immunity in fish [45].

The alanine content was highest in the $N$. intermedia biomass, exceeding that of fishmeal. This amino acid is a major gluconeogenesis precursor, energy supplier, a preferred nitrogen carrier for amino acid metabolism and has stimulatory effects on feeding rate. Aspartate and asparagine comprise around $10 \%$ of the AA in plant and animal proteins. They play roles in stress tolerance under high salinity conditions and changes in other environmental factors during migration [67]. Fungal biomass contains an appropriate level of alanine ( $8 \%$ ) and asparagine $(10.5 \%)$, which are slightly higher than the amount contained by fishmeal and can address the concerns regarding dietary supplementation of these amino acids when fungal biomass is used as a protein source in a fish diet.

Regarding amino acid composition, the fungal biomass contains a higher percentage of serine and threonine than fishmeal, while fishmeal is richer in glycine, lysine, and methionine. Serine participates in gluconeogenesis, sulfur amino acid metabolism, and fat digestion [68]. Serine also stimulates feed intake for many fish species [69]. It is presumed that serine content can compensate for the insufficiency of sulfur-based amino acids, such as methionine and cysteine [45]. Threonine is normally found in limited amounts in plants; it is, however, insufficient to feed fish with protein only derived from plants. Dietary threonine levels can affect immunity responses, like in mammals [61]. In addition, threonine is the primary component of mucin in the small intestine and, therefore, plays an important role in maintaining the intestinal barrier integrity and function [58]. Although the potential use of threonine in aqua-feed has received little attention, its requirement has nonetheless been assessed to be $2-4 \%$ of total amino acids, which is matched by the $5 \%$ threonine content of the fungal biomass [45]. 
Compared with SBM, fungal biomass contains a higher proportion of alanine, cysteine, glycine, lysine, methionine, proline, threonine, tyrosine, and valine, while SBM is richer in arginine, asparagine, glutamine, histidine, and phenylalanine. The content levels of isoleucine, leucine, and serine are comparable in SBM and fungal biomass. Riley et al. [70] showed that that dietary supplementation of glycine increased hepatic thyroxine 50 monodeiodinase activity in rainbow trout, which enhances the efficiency of nutrient absorption and anabolic events. Facilitating $\mathrm{T}_{4}$ to $\mathrm{T}_{3}$ conversion, which are more active types of thyroid hormones, is a direct effect of the dietary inclusion of glycine. Thyroid hormones act to increase the basal metabolic level and protein synthesis. Therefore, they can affect the growth status of organisms [71]. The proline and methionine content of fungal biomass is higher than that of SBM. Proline is considered a dispensable amino acid in fish and can be derived from other amino acids like arginine, ornithine, and glutamic acid. However, this mechanism is not clear in fish, and proline is categorized as conditionally EAA. Methionine is usually the first limiting amino acid in many fish diets, especially when the fish diet contains a high proportion of plant protein sources, such as soybean meal and crop meal [51].

According to the amount of each amino acid (g/Kg DM), between the three species investigated in the present study, N. intermedia had the highest total amino acid content, except for proline, which was highest in R. oryzae. Ornithine was at its highest level in A. oryzae. Ornithine can be used for the synthesis of proline and polyamines and plays a crucial role in the synthesis of arginine in the urea cycle.

Histidine is one of most abundant amino acids in fish plasma [72]. Histidine is involved in one-carbon metabolism and, therefore, has a positive influence on DNA and protein synthesis. In addition to serving as an energy fuel during starvation, histidine is a major component of noncarbonated buffers that protect fish against changes in $\mathrm{pH}$ resulting from hypoxia. Histidine and its related imidazole derivatives (anserine and carnosine) induce a desirable taste (e.g., sweetness, heaviness, and thickness), so supplementation of histidine in the diet can improve the sensory attributes (e.g., flavor) of fish feed [73]. Additionally, R. oryzae is richer in isoleucine, lysine, methionine, phenylalanine, and proline compared to the other two fungal species.

\subsubsection{Lipid and Fatty acid Composition of the Fungal Biomass Cultivated in Vinasse}

The results for the lipid content and fatty acid profile of fungal biomass are presented in Table 4 . The lipid contents of the investigated fungi species were $7.0 \%, 5.5 \%$, and $3.5 \%$ for A. oryzae, R. oryzae, and N. intermedia, respectively. However, from the perspective of protein content, our fungal species showed an opposite order of importance. The constituents and nutritional properties of the fungal biomass are significantly related to the cultivation medium and conditions [41]. It was observed that vinasse has a good potential to support lipid deposition in fungal biomass. Usually, dietary fat inclusion in a fish diet is provided by fish oil and other vegetable oils, but it seems that having high enough lipid content and a good fatty acid profile in a fungal biomass can improve a feed's nutritional quality. Apart from the fact that lipids, as a macronutrient, are the main source of energy, it is not simple to define the exact "optimum" level of dietary lipids for any species, though there is a range within which dietary lipids should be supplied [48]. Most lipid fatty acids have several key functions in the body and preparing appropriate lipid content in the feed will have a "protein sparing effect" [45]. Many farmed fish species can utilize lipids in up to $20 \%$ of the dry weight of their diet, which means that protein can be effectively utilized and support growth without depositing excessive lipids in the tissues [74]. Since more than $85 \%$ of all farmed fish are freshwater fish species, such as carp and tilapia, and have moderate dietary energy and protein requirements (Tacon et al., 2010), filamentous fungal biomass is a potential supplement to be used as a protein source in aquafeed.

While the concentration of fatty acids varied in each biomass, the highest proportions of fatty acids in all three fungal biomasses were for oleic acid (C18:1), linoleic acid (C18:2) (LA), and palmitic acid (C16:0). In addition to serving as an energy source throughout oxidation, palmitic acid has antioxidant effects [75]. Moreover, a much better taste is reported when rainbow trout were fed with a diet containing sunflower oil instead of fish oil, the former of which contains higher amount of oleic acid [76]. Skonberg, 
Yogev, Hardy, and Dong [76] reported that these fish fillets contain lower levels of PUFAs and are more resistant to oxidation.

According to beneficial health properties described below, the most important fatty acids in fish nutrition are LA, alpha linolenic acid (ALA), and arachidonic acid (ARA). Fungal biomass contains a valuable amount of these fatty acids. The $\omega 3$ and $\omega 6$ fatty acids represent two classes of PUFAs that are derived from ALA (18:3n-3) and LA (18:2n-6), respectively [77]. ARA, an important PUFA derived from LA, is a precursor for eicosanoid production, which is important in immune responses and cell signaling [78]. ARA content up to $1 \%$ and $1.5 \%$ of the dry weight of a diet was found to improve growth in larval sea bream (Bessonart et al., 1999) and larval Japanese flounder (Estevez et al., 1997), respectively. Therefore, there is qualitative evidence on the importance and probable essentiality of dietary arachidonic acid (20:4n-6) for the optimal growth and development of marine fish larvae (Rodriguez et al., 1994; Ishizaki et al., 1998; Estevez et al., 1999; Bessonart et al., 1999). Recently, the role of ARA in the metamorphosis of marine fish and crustaceans has also been reported [79]. ALA is the precursor of two important longer chain omega-3 fatty acids, EPA and DHA, which have vital roles in brain development, cardiovascular health, and inflammatory responses [80]. While A. oryzae contains high levels of LA and ARA, the maximum ALA concentration was measured in the N. intermedia biomass. In addition, $N$. intermedia contains the highest PUFA/SFA ratio, which makes it a potential high-quality source for PUFAs. Hence, the inclusion of $N$. intermedia in a diet could benefit cold water fish species like salmonids, which have high ALA requirements. Comparing the fungal biomass fatty acid profile with SBM (Table 4), the most common alternative protein source for fishmeal, it can be seen that the concentrations of palmitic, myristic, palmitoleic, stearic, oleic acid, and linoleic acids are higher than SBM, while they contain less linolenic acid than SBM. The presence of higher LA content is a benefit fungal biomass. Fish, especially cold freshwater fish species, have the capacity to synthesize LC-PUFA from C18 PUFAs, such as linoleic and linolenic acids [81]. In the case of freshwater fish, a 1\% inclusion of C18 PUFA linoleic and linolenic acids could be satisfactory for growth.

\subsubsection{Minerals}

Macro-minerals have vital functions in the animal body. They are a component of skeletal and other hard tissues such as the exoskeleton, teeth, fin rays, etc., and engage in electron transfer, acid-base balance regulation, cell membrane properties, and osmoregulation [82]. The mineral composition of the fungal biomass was analyzed to assess the nutritional quality of the biomass' mineral supplementation. Mineral content data, including $\mathrm{Ca}, \mathrm{K}, \mathrm{Mg}, \mathrm{Na}, \mathrm{P}$, and $\mathrm{S}$, are presented in Table 5 . The results show that $A$. oryzae, $N$. intermedia, and $R$. oryzae contain considerable levels of all these elements in order of importance. The minerals with the highest concentration in the fungal biomass were $\mathrm{Ca}, \mathrm{K}$, and $\mathrm{P}$, respectively. Between these three fungi species, $N$. intermedia contained higher amounts of $\mathrm{Ca}, \mathrm{K}$, and $\mathrm{S}$, while the concentrations of $\mathrm{Mg}, \mathrm{Na}$, and $\mathrm{P}$ were higher in $\mathrm{R}$. oryzae. The dietary mineral requirement is highly variable among fish and crustacean species [81]. From a nutritional point of view, the supplementation of minerals is very important, especially in crustacean rearing and breeding practices. According to the NRC [45], the Ca, $\mathrm{P}$, and $\mathrm{K}$ dietary requirements of fish and shrimp ranges between 3.5-15, 5-13, and $2-12 \mathrm{~g} / \mathrm{Kg}$, respectively. Considering the mineral content of the fungal biomass, the inclusion of these fungal biomasses could adequately meet the dietary requirements of fish and shrimp.

$\mathrm{Ca}$ and $\mathrm{P}$ are the primary mineral components of a complete diet. Ca is involved in blood clotting (vertebrates), muscle functions (such as contractions), nerve impulse transmission, osmoregulation, membrane permeability, hormone and enzyme secretions, and acts as a structural component of teeth and bones. In addition, $\mathrm{P}$ is a component of nucleotides, skeletal tissues, phospholipids, coenzymes, DNA, RNA, and special enzymes involved in energy production $[83,84]$. Moreover, $\mathrm{P}$ has a buffering effect and helps an organism maintain a normal $\mathrm{pH}$ [85]. Compared to FM, fungal biomass has a higher $\mathrm{K}$ content. However, FM was richer in other mineral elements. On the other hand, the fungal biomass is superior to SBM in its higher content of $\mathrm{Na}, \mathrm{P}, \mathrm{S}$, and $\mathrm{Ca}$. $\mathrm{K}$ is an essential macro mineral used particularly to balance the acid-base equilibrium, as well as for osmoregulation and maintaining 
muscle and nerve activity. If these minerals are not supplied at sufficient levels in the diet, the organism will become susceptible to different pathological problems [86]. For example, a deficiency in P will lead to a reduction in growth capacity and feed conversion, skeletal malformation, intermediary metabolism impairment, a reduction in tissue hardness, a reduction in antibody production, and reduced weight gain $[84,85]$.

Table 5. Macro mineral content of A. oryzae, N. intermedia, and R. oryzae, fishmeal (FM), and soybean meal (SBM).

\begin{tabular}{cccccc}
\hline Mineral (g/Kg) & A. oryzae & N. intermedia & R. oryzae & FM & SBM \\
\hline Ca & 23.8 & 58.5 & 26.4 & 55.4 & 3.4 \\
K & 12.0 & 15.8 & 8.9 & 7.4 & 21.2 \\
$\mathbf{P}$ & 9.1 & 8.9 & 16.4 & 31.0 & 6.2 \\
$\mathbf{M g}$ & 0.9 & 0.8 & 1.2 & 2.6 & 2.9 \\
$\mathbf{N a}$ & 1.1 & 1.3 & 1.6 & 11.2 & 0.0 \\
$\mathbf{S}$ & 4.7 & 4.8 & 3.9 & 7.4 & ND \\
\hline
\end{tabular}

\section{Conclusions}

The potential of the application of filamentous fungal biomass cultivated on vinasse as a dietary protein source in a fish diet was thoroughly assessed in this study. Vinasse, as a low-value substrate, shows great potential to yield high concentrations of a protein-rich fungal biomass up to $118.5 \mathrm{~g} / \mathrm{L}$ (A. oryzae). Moreover, as a promising protein source supplement, a fungal biomass grown on vinasse has the possibility to contain up to $57 \%$ protein (dry biomass) in N. intermedia. In addition to its high protein content, the noticeable compatibility of the obtained fungal biomass' amino acid profile, fatty acid profile, and mineral content, compared to fishmeal, supports the possibility of fungal biomass inclusion in a fish diet. Overall, based on the acquired results, it is of great probability that the application of a fungal biomass grown on organic-rich, low-value residual streams, such as vinasse, can remediate the challenges arising from fishmeal shortage and facilitate sustainable aquaculture development.

Author Contributions: Conceptualization, M.J.T., N.M.S.; methodology, A.M., S.K., T.L.; Data curation, S.K., T.L., M.J.T.; validation, S.K., M.J.T., N.M.S.; formal analysis, T.L., S.K.; resources, M.J.T., N.M.S., T.L. writing一original draft preparation, S.K., A.M.; writing—review and editing, M.J.T., N.M.S., T.L., A.K.; supervision, M.J.T., N.M.S.

Funding: This research received no external funding.

Acknowledgments: The authors would like to express their gratitude to the European Regional Development Fund "Waste2Taste," Lantmännen Agroetanol (Sweden), Swedish University of Agricultural Sciences (SLU, Sweden) and Isfahan University of Technology (Iran) for their technical and financial support of this work.

Conflicts of Interest: The authors declare no conflict of interest.

\section{References}

1. FAO. The State of World Fisheries and Aquaculture 2018; European Commission: Brussels, Belgium, 2018; p. 227.

2. Moffitt, C.M.; Cajas-Cano, L. Blue Growth: The 2014 FAO State of World Fisheries and Aquaculture. Fisheries 2014, 39, 552-553. [CrossRef]

3. Monge-Ortiz, R.; Tomas-Vidal, A.; Gallardo-Alvarez, F.J.; Estruch, G.; Godoy-Olmos, S.; Jover-Cerda, M.; Martinez-Llorens, S. Partial and total replacement of fishmeal by a blend of animal and plant proteins in diets for Seriola dumerili: Effects on performance and nutrient efficiency. Aquac. Nutr. 2018, 24, 1163-1174. [CrossRef]

4. Tibbetts, S.M.; Mann, J.; Dumas, A. Apparent digestibility of nutrients, energy, essential amino acids and fatty acids of juvenile Atlantic salmon (Salmo salar L.) diets containing whole-cell or cell-ruptured Chlorella vulgaris meals at five dietary inclusion levels. Aquaculture 2017, 481, 25-39. [CrossRef]

5. Tacon, A.G.J.; Metian, M. Global overview on the use of fish meal and fish oil in industrially compounded aquafeeds: Trends and future prospects. Aquaculture 2008, 285, 146-158. [CrossRef] 
6. Ngo, D.T.; Pirozzi, I.; Glencross, B. Digestibility of canola meals in barramundi (Asian seabass; Lates calcarifer). Aquaculture 2015, 435, 442-449. [CrossRef]

7. Smith, A.A.; Dumas, A.; Yossa, R.; Overturf, K.E.; Bureau, D.P. Effects of soybean meal and high-protein sunflower meal on growth performance, feed utilization, gut health and gene expression in Arctic charr (Salvelinus alpinus) at the grow-out stage. Aquac. Nutr. 2018, 24, 1540-1552. [CrossRef]

8. Vidakovic, A.; Langeland, M.; Sundh, H.; Sundell, K.; Olstorpe, M.; Vielma, J.; Kiessling, A.; Lundh, T. Evaluation of growth performance and intestinal barrier function in Arctic Charr (Salvelinus alpinus) fed yeast (Saccharomyces cerevisiae), fungi (Rhizopus oryzae) and blue mussel (Mytilus edulis). Aquac. Nutr. 2016, 22, 1348-1360. [CrossRef]

9. Davies, S.J.; Morris, P.C. Influence of multiple amino acid supplementation on the performance of rainbow trout, Oncorhynchus mykiss (Walbaum), fed soya based diets. Aquac. Res. 1997, 28, 65-74. [CrossRef]

10. Krogdahl, A.; Bakke-McKellep, A.M.; Baeverfjord, G. Effects of graded levels of standard soybean meal on intestinal structure, mucosal enzyme activities, and pancreatic response in Atlantic salmon (Salmo salar L.). Aquac. Nutr. 2003, 9, 361-371. [CrossRef]

11. Allameh, S.K.; Soofiani, N.M.; Pourreza, J. Determination of digestible and metabolizable energy of fishmeal and soybean meal in rainbow trout with two different sizes (Oncorhynchus mykiss). Pak. J. Biol. Sci. PJBS 2007, 10, 3722-3725.

12. Glencross, B.; Hawkins, W. A comparison of the digestibility of lupin (Lupinus sp.) kernel meals as dietary protein resources when fed to either, rainbow trout, Oncorhynchus mykiss or red seabream, Pagrus auratus. Aquac. Nutr. 2004, 10, 65-73. [CrossRef]

13. Burel, C.; Boujard, T.; Tulli, F.; Kaushik, S.J. Digestibility of extruded peas, extruded lupin, and rapeseed meal in rainbow trout (Oncorhynchus mykiss) and turbot (Psetta maxima). Aquaculture 2000, 188, 285-298. [CrossRef]

14. Overland, M.; Sorensen, M.; Storebakken, T.; Penn, M.; Krogdahl, A.; Skrede, A. Pea protein concentrate substituting fish meal or soybean meal in diets for Atlantic salmon (Salmo salar)-Effect on growth performance, nutrient digestibility, carcass composition, gut health, and physical feed quality. Aquaculture 2009, 288, 305-311. [CrossRef]

15. Luo, L.; Xue, M.; Wu, X.; Cai, X.; Cao, H.; Liang, Y. Partial or total replacement of fishmeal by solvent-extracted cottonseed meal in diets for juvenile rainbow trout (Oncorhynchus mykiss). Aquac. Nutr. 2006, 12, 418-424. [CrossRef]

16. Watanabe, T.; Takeuchi, T.; Satoh, S.; Kiron, V. Digestible crude protein contents in various feedstuffs determined with four freshwater fish species. Fish. Sci. 1996, 62, 278-282. [CrossRef]

17. Farhangi, M.; Carter, C.G. Growth, physiological and immunological responses of rainbow trout (Oncorhynchus mykiss) to different dietary inclusion levels of dehulled lupin (Lupinus angustifolius). Aquac. Res. 2001, 32, 329-340. [CrossRef]

18. Francis, G.; Makkar, H.P.S.; Becker, K. Antinutritional factors present in plant-derived alternate fish feed ingredients and their effects in fish. Aquaculture 2001, 199, 197-227. [CrossRef]

19. Hardy, R.W.; Sealey, W.M.; Gatlin, D.M. Fisheries by-catch and by-product meals as protein sources for rainbow trout Oncorhynchus mykiss. J. World Aquac. Soc. 2005, 36, 393-400. [CrossRef]

20. El-Haroun, E.R.; Azevedo, P.A.; Bureau, D.P. High dietary incorporation levels of rendered animal protein ingredients on performance of rainbow trout Oncorhynchus mykiss (Walbaum, 1972). Aquaculture 2009, 290, 269-274. [CrossRef]

21. Millamena, O.M. Replacement of fish meal by animal by-product meals in a practical diet for grow-out culture of grouper Epinephelus coioides. Aquaculture 2002, 204, 75-84. [CrossRef]

22. Bureau, D.P.; Harris, A.M.; Bevan, D.J.; Simmons, L.A.; Azevedo, P.A.; Cho, C.Y. Feather meals and meat and bone meals from different origins as protein sources in rainbow trout (Oncorhynchus mykiss) diets. Aquaculture 2000, 181, 281-291. [CrossRef]

23. Karimi, S.; Soofiani, N.M.; Mahboubi, A.; Taherzadeh, M.J. Use of Organic Wastes and Industrial By-Products to Produce Filamentous Fungi with Potential as Aqua-Feed Ingredients. Sustain. Basel 2018, 10, 3296. [CrossRef]

24. Ferreira, J.A.; Mahboubi, A.; Lennartsson, P.R.; Taherzadeh, M.J. Waste biorefineries using filamentous ascomycetes fungi: Present status and future prospects. Bioresour. Technol. 2016, 215, 334-345. [CrossRef] [PubMed]

25. Akram, M.; Tan, C.K.; Garwood, R.; Thai, S.M. Vinasse-A potential biofuel—Cofiring with coal in a fluidised bed combustor. Fuel 2015, 158, 1006-1015. [CrossRef] 
26. Aparicio, J.D.; Benimeli, C.S.; Almeida, C.A.; Polti, M.A.; Colin, V.L. Integral use of sugarcane vinasse for biomass production of actinobacteria: Potential application in soil remediation. Chemosphere 2017, 181, 478-484. [CrossRef]

27. Santana, H.; Cereijo, C.R.; Teles, V.C.; Nascimento, R.C.; Fernandes, M.S.; Brunale, P.; Campanha, R.C.; Soares, I.P.; Silva, F.C.P.; Sabaini, P.S.; et al. Microalgae cultivation in sugarcane vinasse: Selection, growth and biochemical characterization. Bioresour. Technol. 2017, 228, 133-140. [CrossRef]

28. Nair, R.B.; Taherzadeh, M.J. Valorization of sugar-to-ethanol process waste vinasse: A novel biorefinery approach using edible ascomycetes filamentous fungi. Bioresour. Technol. 2016, 221, 469-476. [CrossRef]

29. Ahmed, P.M.; Pajot, H.F.; de Figueroa, L.I.C.; Gusils, C.H. Sustainable bioremediation of sugarcane vinasse using autochthonous macrofungi. J. Environ. Chem. Eng. 2018, 6, 5177-5185. [CrossRef]

30. dos Santos, J.D.; da Silva, A.L.L.; Costa, J.D.; Scheidt, G.N.; Novak, A.C.; Sydney, E.B.; Soccol, C.R. Development of a vinasse nutritive solution for hydroponics. J. Environ. Manag. 2013, 114, 8-12. [CrossRef]

31. Candido, C.; Lombardi, A.T. The physiology of Chlorella vulgaris grown in conventional and biodigested treated vinasses. Algal Res. 2018, 30, 79-85. [CrossRef]

32. Engin, I.K.; Cekmecelioglu, D.; Yucel, A.M.; Oktem, H.A. Evaluation of heterotrophic and mixotrophic cultivation of novel Micractinium sp ME05 on vinasse and its scale up for biodiesel production. Bioresour. Technol. 2018, 251, 128-134. [CrossRef]

33. Ramirez, N.N.V.; Farenzena, M.; Trierweiler, J.O. Growth of Microalgae Scenedesmus sp in Ethanol Vinasse. Braz. Arch. Biol. Technol. 2014, 57, 630-635. [CrossRef]

34. Nitayavardhana, S.; Khanal, S.K. Innovative biorefinery concept for sugar-based ethanol industries: Production of protein-rich fungal biomass on vinasse as an aquaculture feed ingredient. Bioresour. Technol. 2010, 101, 9078-9085. [CrossRef]

35. Nitayavardhana, S.; Issarapayup, K.; Pavasant, P.; Khanal, S.K. Production of protein-rich fungal biomass in an airlift bioreactor using vinasse as substrate. Bioresour. Technol. 2013, 133, 301-306. [CrossRef]

36. Sluiter, A.; Hames, B.; Ruiz, R.; Scarlata, C.; Sluiter, J.; Templeton, D.; Crocker, D. Determination of structural carbohydrates and lignin in biomass. In Laboratory Analytical Procedure (LAP); NREL: Golden, CO, USA, 2008.

37. Bahlsberg-Pålsson, A.M. Förbehandling, uppslutning och extraktberedning av växt-och förnaprov. In $I$ Handledning I Kemiska Metoder Vid Växtekologiska Arbeten; Meddelande från Växtekologiska avdelningen, Lunds Universitet: Lund, Sweden, 1990.

38. Langeland, M.; Vidakovic, A.; Vielma, J.; Lindberg, J.E.; Kiessling, A.; Lundh, T. Digestibility of microbial and mussel meal for Arctic charr (Salvelinus alpinus) and Eurasian perch (Perca fluviatilis). Aquac. Nutr. 2016, 22, 485-495. [CrossRef]

39. Folch, J.; Lees, M.; Stanley, G.H.S. A Simple Method for the Isolation and Purification of Total Lipides from Animal Tissues. J. Biol. Chem. 1957, 226, 497-509.

40. Appelqvist, L.- $\AA$. Rapid methods of lipid extraction and fatty acid methyl ester preparation for seed and leaf tissue with special remarks on preventing the accumulation of lipid contaminants. Ark. För Kemi 1968, 28, 551-570.

41. Mahboubi Soufiani, A.; Ferreira, J.; Taherzadeh, M.; Lennartsson, P. Production of Fungal Biomass for Feed, Fatty Acids, and Glycerol by Aspergillus oryzae from Fat-Rich Dairy Substrates. Fermentation 2017, 3, 48. [CrossRef]

42. Ghasemian, A.; Asadollahzadeh, M.; Saraeian, A.; Resalati, H.; Taherzadeh, M. Effect of Acetic Acid on Growth and Ethanol Fermentation of Filamentous Fungi Rhizopus oryzae, Mucor indicus, Neurospora intermedia and Aspergilus oryzae. J. Exp. Anim. Sci. 2019, 7, 119-130.

43. FazeliNejad, S.; Ferreira, J.A.; Brandberg, T.; Lennartsson, P.R.; Taherzadeh, M.J. Fungal biomass and ethanol from lignocelluloses using Rhizopus pellets under simultaneous saccharification, filtration, and fermentation (SSFF). Biofuel. Res. J. 2016, 3, 372-378. [CrossRef]

44. Ytrestoyl, T.; Aas, T.S.; Asgard, T. Utilisation of feed resources in production of Atlantic salmon (Salmo salar) in Norway. Aquaculture 2015, 448, 365-374. [CrossRef]

45. NRC. Nutrient Requirements of Fish and Shrimp; The National Academies Press: Washington, DC, USA, 2011; p. 392. ISBN 978-0-309-47322-4.

46. National Research Council. Nutrient Requirements of Swine: Eleventh Revised Edition; The National Academies Press: Washington, DC, USA, 2012; p. 420. [CrossRef] 
47. Sauvant, D.; Perez, J.-M.; Tran, G. Tables of Composition and Nutritional Value of Feed Materials: Pigs, Poultry, Cattle, Sheep, Goats, Rabbits, Horses and Fish; Wageningen Academic Publishers: Wageningen, The Netherlands, 2004.

48. Jobling, M. Feeding and digestive functions in fishes-Edited by J. E. P. Cyrino, D. Bureau and B. G. Kapoor. J. Fish Biol. 2009, 75, 756-757. [CrossRef]

49. Mariotti, F.; Tome, D.; Mirand, P.P. Converting nitrogen into Protein-Beyond 6.25 and Jones' factors. Crit. Rev. Food Sci. 2008, 48, 177-184. [CrossRef] [PubMed]

50. Stajich, J. Cellular and Molecular Biology of Filamentous Fungi; illBorkovich, K., Ebbole, D.J., Eds.; \$209.95. xiii + 788 p.; ASM Press: Washington, DC, USA, 2010; Volume 86, p. 59. ISBN 978-1-55581-473-1.

51. Wang, Y.Y.; Che, J.F.; Tang, B.B.; Yu, S.L.; Wang, Y.Y.; Yang, Y.H. Dietary methionine requirement of juvenile Pseudobagrus ussuriensis. Aquac. Nutr. 2016, 22, 1293-1300. [CrossRef]

52. Moughan, P.J.; Rutherfurd, S.M. A new method for determining digestible reactive lysine in foods. J. Agric. Food Chem. 1996, 44, 2202-2209. [CrossRef]

53. Walton, M.J.; Cowey, C.B.; Adron, J.W. The Effect of Dietary Lysine Levels on Growth and Metabolism of Rainbow-Trout (Salmo-Gairdneri). Br. J. Nutr. 1984, 52, 115-122. [CrossRef] [PubMed]

54. Chiu, Y.N.; Austic, R.E.; Rumsey, G.L. Effect of Feeding Level and Dietary Electrolytes on the Arginine Requirement of Rainbow-Trout (Salmo-Gairdneri). Aquaculture 1988, 69, 79-91. [CrossRef]

55. Hamid, S.N.I.N.; Abdullah, M.F.; Zakaria, Z.; Yusof, S.J.H.M.; Abdullah, R. Formulation of Fish Feed with Optimum Protein-bound Lysine for African Catfish (Clarias Gariepinus) Fingerlings. Procedia Eng. 2016, 148, 361-369. [CrossRef]

56. Michelato, M.; Vidal, L.V.D.; Xavier, T.O.; de Moura, L.B.; de Almeida, F.L.A.; Pedrosa, V.B.; Furuya, V.R.B.; Furuya, W. Dietary lysine requirement to enhance muscle development and fillet yield of finishing Nile tilapia. Aquaculture 2016, 457, 124-130. [CrossRef]

57. Nguyen, L.; Davis, D.A. Comparison of crystalline lysine and intact lysine used as a supplement in practical diets of channel catfish (Ictalurus punctatus) and Nile tilapia (Oreochromis niloticus). Aquaculture 2016, 464, 331-339. [CrossRef]

58. Li, P.; Mai, K.; Trushenski, J.; Wu, G. New developments in fish amino acid nutrition: Towards functional and environmentally oriented aquafeeds. Amino Acids 2009, 37, 43-53. [CrossRef]

59. Kaushik, S.J.; Gomes, E.F. Effect of Frequency of Feeding on Nitrogen and Energy-Balance in Rainbow-Trout under Maintenance Conditions. Aquaculture 1988, 73, 207-216. [CrossRef]

60. Zhou, Q.-C.; Zeng, W.-P.; Wang, H.-L.; Xie, F.-J.; Zheng, C.-Q. Dietary arginine requirement of juvenile yellow grouper Epinephelus awoara. Aquaculture 2012, 350, 175-182. [CrossRef]

61. Li, P.; Yin, Y.L.; Li, D.; Kim, S.W.; Wu, G.Y. Amino acids and immune function. Br. J. Nutr. 2007, 98, $237-252$. [CrossRef]

62. Buentello, J.A.; Reyes-Becerril, M.; Romero-Geraldo, M.D.; Ascencio-Valle, F.D. Effects of dietary arginine on hematological parameters and innate immune function of channel catfish. J. Aquat. Anim. Health 2007, 19, 195-203. [CrossRef]

63. Buentello, J.A.; Gatlin, D.M. Effects of elevated dietary arginine on resistance of channel catfish to exposure to Edwardsiella ictaluri. J. Aquat. Anim. Health 2001, 13, 194-201. [CrossRef]

64. Yao, K.; Yin, Y.L.; Chu, W.Y.; Li, Z.Q.; Deng, D.; Li, T.J.; Huang, R.L.; Zhang, J.S.; Tan, B.; Wang, W.; et al. Dietary arginine supplementation increases mTOR signaling activity in skeletal muscle of neonatal pigs. J. Nutr. 2008, 138, 867-872. [CrossRef]

65. Nakashima, K.; Yakabe, Y.; Ishida, A.; Yamazaki, M.; Abe, H. Suppression of myofibrillar proteolysis in chick skeletal muscles by alpha-ketoisocaproate. Amino Acids 2007, 33, 499-503. [CrossRef]

66. Wu, G.Y. Intestinal mucosal amino acid catabolism. J. Nutr. 1998, 128, 1249-1252. [CrossRef]

67. Bystriansky, J.S.; Frick, N.T.; Ballantyne, J.S. Intermediary metabolism of Arctic char Salvelinus alpinus during short-term salinity exposure. J. Exp. Biol. 2007, 210, 1971-1985. [CrossRef]

68. Fang, Y.Z.; Yang, S.; Wu, G.Y. Free radicals, antioxidants, and nutrition. Nutrition 2002, 18, 872-879. [CrossRef]

69. Shamushaki, V.A.J.; Kasumyan, A.O.; Abedian, A.; Abtahi, B. Behavioural responses of the Persian sturgeon (Acipenser persicus) juveniles to free amino acid solutions. Mar. Freshw. Behav. Physiol. 2007, 40, $219-224$. [CrossRef]

70. Riley, W.W.; Higgs, D.A.; Dosanjh, B.S.; Eales, J.G. Influence of dietary arginine and glycine content on thyroid function and growth of juvenile rainbow trout, Oncorhynchus mykiss (Walbaum). Aquac. Nutr. 1996, 2, 235-242. [CrossRef] 
71. Brent, G.A. Mechanisms of thyroid hormone action. J. Clin. Investig. 2012, 122, 3035-3043. [CrossRef]

72. Szebedinszky, C.; Gilmour, K.M. The buffering power of plasma in brown bullhead (Ameiurus nebulosus). Comp. Biochem. Phys. B 2002,131, 171-183. [CrossRef]

73. Ogata, H.Y. Muscle buffering capacity of yellowtail fed diets supplemented with crystalline histidine. J. Fish Biol. 2002, 61, 1504-1512. [CrossRef]

74. Sargent, J.R.; Tocher, D.; Bell, J.G.B. Fish Nutrition; WHOLEY: Pittsburgh, PA, USA, 2002; pp. $181-257$.

75. Elagbar, Z.A.; Naik, R.R.; Shakya, A.K.; Bardaweel, S.K. Fatty Acids Analysis, Antioxidant and Biological Activity of Fixed Oil of Annona muricata L. Seeds. J. Chem. 2016. [CrossRef]

76. Skonberg, D.I.; Yogev, L.; Hardy, R.W.; Dong, F.M. Metabolic response to dietary phosphorus intake in rainbow trout (Oncorhynchus mykiss). Aquaculture 1997, 157, 11-24. [CrossRef]

77. Mori, T.A. Marine OMEGA-3 fatty acids in the prevention of cardiovascular disease. Fitoterapia 2017, 123, 51-58. [CrossRef]

78. Innes, J.K.; Calder, P.C. Omega-6 fatty acids and inflammation. Prostaglandin Leukot. Essent. 2018, 132, 41-48. [CrossRef]

79. Lund, I.; Steenfeldt, S.J.; Banta, G.; Hansen, B.W. The influence of dietary concentrations of arachidonic acid and eicosapentaenoic acid at various stages of larval ontogeny on eye migration, pigmentation and prostaglandin content of common sole larvae (Solea solea L.). Aquaculture 2008, 276, 143-153. [CrossRef]

80. Senadheera, S.; Turchini, G.; Thanuthong, T.; Francis, D. Effects of dietary $\alpha$-linolenic acid (18:3n-3)/linoleic acid (18:2n-6) ratio on growth performance, fillet fatty acid profile and finishing efficiency in Murray cod. Aquaculture 2010, 309, 222-230. [CrossRef]

81. Halver, J.E.; Hardy, R.W. Fish Nutrition; Elsevier: Amsterdam, The Netherlands, 2002.

82. Food and Agriculture Organization; World Health Organization. Vitamin and Mineral Requirements in Human Nutrition; WHO: Geneva, Switzerland, 2005.

83. Takeda, E.; Yamamoto, H.; Yamanaka-Okumura, H.; Taketani, Y. Dietary phosphorus in bone health and quality of life. Nutr. Rev. 2012, 70, 311-321. [CrossRef]

84. Yamauchi, M.; Anderson, J.J.B.; Garner, S.C. Calcium and Phosphorus in Health and Disease; CRC Press: New York, NY, USA, 1996.

85. Fairweather-Tait, S.J.; Cashman, K. Minerals and Trace Elements. World Rev. Nutr. Diet. 2015, 111, 45-52. [CrossRef]

86. He, F.J.; MacGregor, G.A. Beneficial effects of potassium on human health. Physiol. Plant. 2008, 133, 725-735. [CrossRef] 